\title{
Sensory evaluation of provitamin A carotenoid-rich banana cultivars on trial for potential adoption in Burundi and Eastern Democratic Republic of Congo
}

\author{
B. Ekesa ${ }^{1}$, D. Nabuuma1 1 G. Kennedy² and I. Van den Bergh ${ }^{3, a}$ \\ ${ }^{1}$ Bioversity International, P.O. Box 24384, Plot 106, Katalima Road, Naguru, Kampala, Uganda \\ 2 Bioversity International, Via dei Tre Denari, 472/a - 00054 Maccarese, Rome, Italy \\ ${ }^{3}$ Bioversity International, C/O KULeuven, W. De Croylaan 42, bus 2455, 3001 Leuven, Belgium
}

\section{Summary \\ Introduction - Vitamin A deficiency (VAD) is a} widespread health problem in Eastern Africa where banana is a staple food crop. Research has shown that certain banana cultivars grown outside Eastern Africa are rich in provitamin A carotenoids (pVACs) and could thus be utilized in addressing VAD in the region. The objective of this research was to compare the consumer preference of the pVAC-rich banana cultivars with that of local cultivars of the same genome and following similar postharvest handling treatments. Materials and methods - Evaluation trials of selected pVAC-rich banana cultivars ['Apantu' (AAB, Plantain), 'Bira' (AAB, Iholena), 'Lahi' (AAB, Popo'ulo), 'Pelipita' (ABB), 'Sepi' (AA), 'To'o' (AA), 'Hung Tu' (AA) and 'Laï' (AAA)] were established in Burundi and Eastern Democratic Republic of Congo (DRC). During sensory evaluations 450 panellists $(50 \%$ male and $50 \%$ female) tested the products using standard procedures and rated them on a 5-point hedonic scale. Dessert types were served raw; cooking types were boiled, roasted and pan-fried. The attributes evaluated included: peel appearance, ease of peeling, pulp appearance, aroma, texture in hand, texture in mouth, taste and overall acceptability. Results and discussion - In Burundi, all the cultivars had overall acceptability median scores of 4 (good). In North Kivu, DRC, the overall acceptability medians ranged from fair to very good (3-5). In South Kivu, DRC, the median overall acceptability scores were good (4) for all cultivars except 'To'o' and 'Gros Michel' (AAA) that scored 3 and 5 respectively (fair and very good). In all three sites and for all the cultivars, there was a significant correlation between the scores for texture in the mouth, taste and the scores for overall acceptability. Conclusion - Taste and texture in mouth have proved to be major consumption attributes that determine acceptability of a banana cultivar. A number of the pVAC-rich cultivars have shown good potential for adoption within existing farming systems and diets in these regions.

\section{Keywords}

Eastern Africa, banana, Musa spp., acceptability, genetic resources management, organoleptic quality

\section{Significance of this study}

What is already known on this subject?

- Bananas form a major part of the food and dietary systems of population groups in Burundi and Eastern Democratic Republic of Congo. Local cultivars have significantly lower levels of provitamin A carotenoids (pVACs) as compared to selected landraces originally not from Eastern Africa.

What are the new findings?

- The organoleptic properties of some of the pVAC-rich cultivars compare well with that of local cultivars, suggesting good potential of adoption within existing farming and food systems.

What is the expected impact on horticulture?

- This work enhances the potential of horticulture to contribute to improved nutrition and health by promoting the availability and utilisation of existing pVAC-rich banana cultivars. It also contributes to the conservation of banana landraces through use.

\section{Résumé}

Evaluation sensorielle des cultivars de banane riches en caroténoïdes-provitamine A testés pour leur potentiel d'adoption au Burundi et dans l'Est de la République Démocratique du Congo.

Introduction - La carence en vitamine A est un problème de santé répandu en Afrique de l'Est où la banane est un aliment de base. Des études ont montré que certains cultivars de bananes cultivés ailleurs qu'en Afrique de l'Est sont riches en caroténoïdesprovitamine A (pVACs) et pourraient être utilisés pour s'attaquer aux problèmes de carence en vitamine A dans la région. L'objectif de cette recherche était d'analyser la préférence des consommateurs pour les cultivars riches en pVAC et les cultivarslocaux de même type ayant reçus le même traitement post-récolte. Matériel et méthodes - Des cultivars riches en pVACs ['Apantu' (AAB, Plantain), 'Bira' (AAB, Iholena), 'Lahi' (AAB, Popo'ulo), 'Pelipita' (ABB), 'Sepi' ( AA), 'To'o' (AA), 'Hung Tu' (AA) et 'Laï' (AAA)] ont été évalués au

a Corresponding author: i.vandenbergh@cgiar.org. 
Burundi et dans les provinces du Nord et Sud-Kivu de la République Démocratique du Congo (RDC). Lors d'évaluations sensorielles, 450 évaluateurs $(50 \%$ hommes et $50 \%$ femmes) ont testé les produits et les ont classés sur une échelle hédonique de 1 à 5 . Les bananes desserts ont été servies crues tandis que les bananes à cuire ont été bouillies, rôties ou sautées à la poêle. Les attributs évalués incluaient: l'apparence de la pelure, la facilité d'épluchage, l'arôme, la texture dans la main, la texture en bouche, le goût et l'acceptabilité globale. Résultats et discussion - Au Burundi, le score médian pour l'acceptabilité était de 4 (bon) pour tous les cultivars. Au Nord-Kivu le score médian variait entre 3 et 5 (assez bon et très bon). Au Sud-Kivu le score médian était de 4 (bon) pour tous les cultivars, sauf 'To'o' et 'Gros Michel' (AAA) qui ont obtenu des scores de 3 (assez bon) et 5 (très bon), respectivement. Dans les trois sites et pour tous les cultivars, une corrélation significative a été trouvée entre les scores de texture en bouche et de goût et ceux d'acceptabilité. Conclusion - Le goût et la texture en bouche se sont révélés être les principaux attributs déterminant l'acceptabilité d'un cultivar de banane. De ce fait, certains des cultivars riches en pVACs ont montré un bon potentiel d'adoption dans les systèmes agricoles et les régimes alimentaires existant dans ces régions.

\section{Mots-clés}

Afrique orientale, banane, Musa spp., acceptabilité, gestion des ressources génétiques, qualité organoleptique

\section{Introduction}

Bananas are an important food source for over 100 million people in Sub-Saharan Africa. In the East African highlands and most of the Great Lakes region, banana consumption ranges from 250 to $400 \mathrm{~kg}$ person-1 year-1 $^{-1}$ (UNCST, 2007). Bananas are a major staple food and a source of income for over 50 million smallholder farmers in the region (AATF-Africa, 2012). In the Eastern Democratic Republic of Congo (DRC), bananas are the main staple after cassava, with a consumption rate of 137-174 $\mathrm{kg}$ person-1 $^{-1}$ year-1 $^{-1}$ (Dowiya et al., 2009). In Uganda, Rwanda and Burundi, about 3-11 bananas are consumed per person each day, making them an important source of carbohydrates, vitamins and minerals in the diets of these populations (Davey et al., 2007; UNCST, 2007).

Prevalence of vitamin A deficiencies (VAD) is high in Eastern Africa [39\% in the whole region, and 43, 46, 39, 64 and $49 \%$ in Uganda, Tanzania, Burundi, Rwanda, DRC and Kenya, respectively (IFPRI, 2016)], and way beyond the WHO acceptable level of 15\% (WHO, 2009).

Evaluation of 171 banana genotypes showed a wide variation in provitamin A carotenoids (pVACs) content between banana genome groups, subgroups and cultivars, with values as high as $220 \mathrm{nmol} \mathrm{g}^{-1}$ dry weight (DW) in some genotypes (Davey et al., 2009). Additional work by Ekesa et al. (2013) showed that the level of pVACs in popular banana cultivars in Eastern Africa ranged from 7 to $27 \mathrm{nmol} \mathrm{g-1} \mathrm{DW.} \mathrm{Differen-}$ ces in pVACs content in banana fruit have been attributed to genotype-specific differences as well as the differences in the developmental status of the fruit. Given that certain banana cultivars that are grown outside Eastern Africa have higher levels of pVACs than local cultivars (Davey et al., 2007; Ekesa et al., 2013; Englberger et al., 2003; Fungo and Pillay, 2011), they can be explored for addressing VAD in the region.

Based on the high reliance on banana for food and the results from an additional study that showed $16-27 \%$ of the vitamin A in banana is bio-accessible (Ekesa et al., 2012), pVAC-rich banana cultivars have good potential to be used as an entry point for substantially reducing these high levels of prevalence of VAD within Eastern Africa.

Some of the attributes consumers consider when making banana cultivar purchases include bunch size, number of hands and fingers, colour, taste and texture (Akankwasa et al., 2013). Therefore, the presence of higher-than-average levels of pVACs (Ekesa et al., 2015) and good agronomic characteristics (Ekesa, 2016) are valid reasons to adopt the test banana cultivars. However, if they are not organoleptically acceptable to the target population, their adoption and consumption will be hindered.

The sensory quality of fruits can be evaluated from the flavour and textural attributes. Flavour is a combination of the basic tastes (salty, sweet, sour and bitter), texture in mouth and aroma. Perception of fruit flavour is a composite of sensory responses resulting from compounds such as acids, sugars, volatiles and many other compounds. Texture in mouth is the overall feeling that a food gives in the mouth and is dependent upon biochemical components such as lipid content, cell wall content and composition, particle size and shape, and moisture content (Amboku et al., 2013). When determining sensory acceptability, it is important to assess the different attributes and target consumer preferences of these attributes.

This study aimed to analyze the organoleptic acceptability of eight introduced (I) pVAC-rich cultivars ('Apantu', 'Bira', 'Lahi', 'Pelipita', 'Sepi', 'To'o', 'Laï' and 'Hung Tu') in comparison with at least three local (L) varieties in eight sites in Burundi and Eastern Democratic Republic of Congo (DRC). Based on what is already known about these cultivars from their countries of origin, we hypothesize that their organoleptic properties will be comparable to those of popular local cultivars.

\section{Materials and methods}

\section{Selection of banana cultivars and preparation}

A total of eight banana cultivars (cooking and dessert types) originating from Hawaii, Ghana, the Philippines, Thailand and Papua New Guinea (PNG) (Table 1) were selected for evaluation for possible inclusion in Eastern African farming systems, due to reported levels of total beta-carotene (t$\mathrm{BC}$ ) equivalents that were higher than the average of their genome or subgroup [ranging between $40-95 \mu \mathrm{g} \mathrm{g}^{-1} \mathrm{DW}$, giving a retinol activity equivalent (RAE) of more than $333 \mu \mathrm{g}$ $100 \mathrm{~g}^{-1}$ DW (Caiubi, 2009)].

Field trials were established in North Kivu (3 trial sites), South Kivu ( 3 trial sites) and Burundi ( 2 trial sites). At each trial site, healthy plants were identified by agronomists and bunches harvested when mature (Dadzie and Orchid, 1997). The introduced cooking cultivars 'Apantu', 'Pelipita', 'Bira', 'Lahi' and 'Hung Tu' were compared with local cooking cultivars 'Musilongo', 'Muzuzu', 'Musheba', 'Vulambya', 'Gisahira' and 'Barhebesha'. The introduced dessert cultivars 'Sepi', 'To'o' and 'Laï' were compared with the local dessert cultivars 'Kamaramasenge', 'Kitika Sukari', 'Gros Michel' and 'Poyo' (Table 2). The local cultivars were obtained from farmers after proper identification by the agronomist. 
All harvested bunches were ripened naturally in an aerated room. The dessert cultivars were evaluated fresh and unpeeled at ripening stage 5. The cooking cultivars 'Bira', 'Apantu', 'Musilongo,' 'Muzuzu' and 'Musheba' were cooked at ripening stage 5 , while other cooking types were cooked at stage 3. The ripening stages were estimated based on the peel colour (Stover and Simmons, 1987). The cooking cultivars were prepared by a group of local women on the same date of the evaluation following procedures established through focus group discussions, and served warm (Table 3).

TABLE 1. Banana cultivars introduced for evaluation in Eastern Africa.

\begin{tabular}{lccccc}
\hline Cultivars & Genomes & Subgroups & Clone sets & Types & Country of origin \\
\hline 'Apantu' & AAB & Plantain & False Horn & Cooking & Ghana \\
'Pelipita' & ABB & Pelipita & nd & Cooking & Philippines \\
'Bira' & AAB & Iholena & nd & Cooking & PNG \\
'Lahi' & AAB & Popo'ulu & nd & Cooking & Hawaii \\
'Sepi' & AA & nd & nd & Cooking* & PNG \\
'Hung Tu' & AA & nd & nd & Dessert & PNG \\
'To'o' & AA & nd & nd & Dessert & PNG \\
'Laii' & AAA & Red & nd & Dessert & Thailand \\
\hline
\end{tabular}

* 'Sepi' - though a cooking type according to Arnaud and Horry (1997) - was evaluated as a dessert type in South Kivu, Democratic Republic of Congo, farmers said it could not be cooked because it had a lot of sticky liquid. It showed similar traits as a local beer banana 'Magizi/Ndundu', which is normally eaten as dessert when ripe and also used in making beer. 'Hung Tu' on the other hand - though described as a dessert type - did not get soft after ripening; the South Kivu community therefore decided to evaluate it as a cooking type. nd = no data; $P N G=$ Papua New Guinea.

TABLE 2. Local banana cultivars used for comparison.

\begin{tabular}{|c|c|c|c|c|c|}
\hline Cultivars & Genomes & Subgroups & Clone sets & Types & Country localised \\
\hline 'Muzuzu' & $A A B$ & Plantain & & Cooking & Burundi \\
\hline 'Musilongo' & $A A B$ & Plantain & French Horn & Cooking & North Kivu, DRC \\
\hline 'Musheba' & $A A B$ & Plantain & French & Cooking & South Kivu, DRC \\
\hline 'Gisahira' & AAA & EAHB & & Cooking & Burundi \\
\hline 'Vulambya' & AAA & EAHB & & Cooking & North Kivu, DRC \\
\hline 'Barhebesha' & AAA & EAHB & & Cooking & South Kivu, DRC \\
\hline 'Kamaramasenge' & $A A B$ & nd & & Dessert & Burundi \& North Kivu, DRC \\
\hline 'Poyo' & AAA & Cavendish & & Dessert & Burundi \\
\hline 'Kitika Sukari' & AAA & Cavendish & & Dessert & North Kivu, DRC \\
\hline 'Gros Michel' & AAA & Gros Michel & & Dessert & South Kivu, DRC \\
\hline
\end{tabular}

$\mathrm{DRC}=$ Democratic Republic of Congo.

$\mathrm{nd}=$ no data.

TABLE 3. Cooking procedures for the different banana cultivars.

\begin{tabular}{|c|c|c|}
\hline Cooking methods & Cultivars & Cooking procedures* \\
\hline Boiling without peel & $\begin{array}{l}\text { 'Apantu', 'Bira', 'Lahi', 'Pelipita', 'Hung } \\
\text { Tu', 'Musilongo', 'Musheba', 'Muzuzu', } \\
\text { 'Vulambya', 'Barhebesha', 'Gisahira' }\end{array}$ & $\begin{array}{l}\text { Fingers were cleaned and peeled using a knife, placed in an aluminium } \\
\text { saucepan with enough water to submerge the fingers, covered and boiled } \\
\text { at medium heat for } 15 \mathrm{~min} \text {. }\end{array}$ \\
\hline Roasting with peel & 'Lahi', 'Vulambya', 'Barhebesha', 'Gisahira' & $\begin{array}{l}\text { Fingers were cleaned and roasted on a charcoal stove, turning the fruit } \\
\text { frequently until evenly ready (peel turns completely black but not burnt). } \\
\text { With the peel still on, the fingers were cut into slices. }\end{array}$ \\
\hline Roasting without peel & $\begin{array}{l}\text { 'Apantu', 'Bira', 'Lahi', 'Pelipita', 'Hung Tu', } \\
\text { 'Musilongo' }\end{array}$ & $\begin{array}{l}\text { Fingers were cleaned, peeled by hand, and roasted on a charcoal stove, } \\
\text { turning the fruit frequently until ready (brown on the outside and tender } \\
\text { when pierced). }\end{array}$ \\
\hline Pan frying & $\begin{array}{l}\text { 'Apantu', 'Bira', 'Lahi', 'Pelipita', 'Hung Tu', } \\
\text { 'Musilongo' }\end{array}$ & $\begin{array}{l}\text { Fingers were cleaned, peeled by hand, and cut into bite size ( } 1 / 4 \text { inch thick) } \\
\text { diagonal slices. In a shallow frying pan with about } 1 \text { inch of vegetable } \\
\text { cooking oil, the pieces were fried until golden brown, turning as necessary. }\end{array}$ \\
\hline Dessert & $\begin{array}{l}\text { 'Sepi', 'To'o', 'Laï', ‘Poyo', 'Gros Michel', } \\
\text { 'Kamaramasenge', 'Kitika Sukari' }\end{array}$ & Fingers were cleaned, and covered in a container. \\
\hline
\end{tabular}

* The cultivars were cooked separately in different saucepans. 
TABLE 4. Mean scores for the sensory attributes of local (L) and introduced (I) banana cultivars following different postharvest treatments in Burundi.

\begin{tabular}{|c|c|c|c|c|c|c|c|c|c|c|}
\hline $\begin{array}{l}\text { Postharvest } \\
\text { treatments }\end{array}$ & Cultivars & $N$ & $\begin{array}{c}\text { Peel } \\
\text { appearance }\end{array}$ & $\begin{array}{l}\text { Ease of } \\
\text { peeling }\end{array}$ & $\begin{array}{c}\text { Pulp } \\
\text { appearance }\end{array}$ & Aroma & $\begin{array}{l}\text { Texture } \\
\text { in hand }\end{array}$ & $\begin{array}{l}\text { Texture } \\
\text { in mouth }\end{array}$ & Taste & $\begin{array}{c}\text { Overall } \\
\text { acceptability }\end{array}$ \\
\hline \multirow{7}{*}{$\begin{array}{l}\text { Boiled } \\
\text { without peel }\end{array}$} & 'Apantu' (I) & 30 & & & $3.47 \mathrm{~b}$ & $3.73^{b}$ & 3.43 a & $3.67 \mathrm{~b}$ & $3.90 \mathrm{bc}$ & $3.83^{\mathrm{cd}}$ \\
\hline & 'Bira' (I) & 150 & & & $3.69 \mathrm{bc}$ & $3.56^{b}$ & $3.51 \mathrm{bc}$ & $3.23 \mathrm{a}$ & $3.03 a$ & $3.44 \mathrm{ab}$ \\
\hline & 'Lahi' (I) & 30 & & & $3.37 \mathrm{~b}$ & $3.07 a$ & $3.10^{a}$ & $3.07 a$ & $3.13 a$ & $3.13^{a}$ \\
\hline & 'Pelipita' (I) & 120 & & & $2.82^{a}$ & $3.41 \mathrm{ab}$ & $3.30 \mathrm{a}$ & $3.63^{b}$ & $3.76^{b}$ & $3.57 \mathrm{bc}$ \\
\hline & 'Muzuzu' (L) & 150 & & & $3.97^{\mathrm{cd}}$ & $3.75^{b}$ & $3.78^{c d}$ & $3.99 b c$ & $4.09 c$ & $3.97 \mathrm{~d}$ \\
\hline & 'Gisahira' (L) & 150 & & & $4.21 \mathrm{~d}$ & $4.13^{c}$ & $4.03^{d}$ & $4.22^{c}$ & $4.19 c$ & $4.09 \mathrm{~d}$ \\
\hline & LSD & & & & 0.37 & 0.37 & 0.37 & 0.40 & 0.41 & 0.33 \\
\hline \multirow{5}{*}{$\begin{array}{l}\text { Roasted } \\
\text { with peel }\end{array}$} & 'Bira' (I) & 29 & & & $3.69 b$ & $3.86^{a}$ & $3.62^{a}$ & $3.24 a$ & $3.41 \mathrm{a}$ & $3.59 a$ \\
\hline & 'Lahi' (I) & 29 & & & $3.41^{\mathrm{a}}$ & $3.86^{a}$ & $3.55^{a}$ & $3.62^{\mathrm{ab}}$ & $3.97 \mathrm{~b}$ & $3.79 \mathrm{ab}$ \\
\hline & 'Pelipita' (I) & 120 & & & $3.39 a$ & $3.93 \mathrm{ab}$ & $3.72^{\mathrm{ab}}$ & $3.99 \mathrm{ab}$ & $4.26 \mathrm{~b}$ & $3.99 \mathrm{bc}$ \\
\hline & 'Gisahira' (L) & 149 & & & $4.28 c$ & $4.19 \mathrm{~b}$ & $4.06^{b}$ & $4.48^{b}$ & $4.26^{b}$ & $4.23 c$ \\
\hline & LSD & & & & 0.34 & 0.30 & 0.35 & 0.95 & 0.34 & 0.28 \\
\hline \multirow{4}{*}{$\begin{array}{l}\text { Roasted } \\
\text { without peel }\end{array}$} & 'Apantu' (I) & 30 & & & $4.03^{b}$ & $4.00^{b}$ & $3.83^{b}$ & $3.97 \mathrm{~b}$ & $4.10^{b}$ & $4.00^{b}$ \\
\hline & 'Bira' (I) & 149 & & & $3.64 a$ & $3.53^{a}$ & $3.41 \mathrm{a}$ & $3.36^{a}$ & $3.21 \mathrm{a}$ & $3.48^{a}$ \\
\hline & 'Muzuzu' (L) & 149 & & & $3.84 \mathrm{ab}$ & $3.97 \mathrm{~b}$ & $3.87 \mathrm{~b}$ & $4.09 b$ & $4.22^{\mathrm{b}}$ & $4.06^{b}$ \\
\hline & LSD & & & & 0.37 & 0.35 & 0.36 & 0.37 & 0.38 & 0.29 \\
\hline \multirow{7}{*}{ Pan-fried } & 'Apantu' (I) & 30 & & & $3.63^{b}$ & $3.87 \mathrm{ab}$ & $3.63 b$ & $3.90 \mathrm{bc}$ & $3.93 b c$ & $3.90^{b}$ \\
\hline & 'Bira' (I) & 150 & & & $4.31 \mathrm{~d}$ & $4.07 b c$ & $3.96^{b}$ & $3.93^{b}$ & $3.94 \mathrm{bc}$ & $4.04 b$ \\
\hline & 'Lahi' (I) & 150 & & & $3.60^{b}$ & $3.93 \mathrm{bc}$ & $3.30 \mathrm{a}$ & $3.37 a$ & $3.47 a$ & $3.47 a$ \\
\hline & 'Pelipita' (I) & 120 & & & $3.23^{a}$ & $3.48^{a}$ & $3.40^{a}$ & $3.60^{a c}$ & $3.71^{\mathrm{ab}}$ & $3.57^{a}$ \\
\hline & 'Muzuzu' (L) & 150 & & & $3.94 \mathrm{bc}$ & $3.91 \mathrm{bc}$ & $3.88^{b}$ & $4.13^{\mathrm{bd}}$ & $4.22^{\mathrm{cd}}$ & $4.07 \mathrm{~b}$ \\
\hline & ‘Gisahira' (L) & 150 & & & $4.17 \mathrm{~cd}$ & $4.25 c$ & $3.99 \mathrm{~b}$ & $4.27 \mathrm{~d}$ & $4.38 \mathrm{~d}$ & $4.21 \mathrm{c}$ \\
\hline & LSD & & & & 0.35 & 0.34 & 0.35 & 0.36 & 0.35 & 0.29 \\
\hline \multirow{5}{*}{ Dessert } & 'To'o' (I) & 30 & $3.50 \mathrm{a}$ & $2.97 a$ & $3.90^{a}$ & & $3.47 a$ & $3.47 a$ & $3.87 \mathrm{~b}$ & $3.83^{a}$ \\
\hline & ‘Laï' (I) & 120 & $3.89 b$ & $3.76^{b}$ & $4.00 \mathrm{a}$ & & $3.49 a$ & $3.36 \mathrm{a}$ & $3.38 \mathrm{a}$ & $3.64 a$ \\
\hline & 'Kamaramasenge' (L) & 90 & $4.41 \mathrm{c}$ & $4.23 c$ & $4.09 \mathrm{a}$ & & $4.23^{b}$ & $4.63^{b}$ & $4.74 c$ & $4.43^{b}$ \\
\hline & 'Poyo' (L) & 60 & $4.40^{b}$ & $4.35^{c}$ & $3.77^{\mathrm{a}}$ & & $3.93^{b}$ & $4.50^{\mathrm{b}}$ & $4.57^{c}$ & $4.40^{\mathrm{b}}$ \\
\hline & LSD & & 0.27 & 0.31 & 0.33 & & 0.37 & 0.35 & 0.33 & 0.27 \\
\hline
\end{tabular}

Means in the same column under the same postharvest treatment followed by the same letter are not significantly different $(P<0.05)$.

$N=$ number of banana samples.

Evaluation scale: 1 - Very bad; 2 - Bad; 3 - Fair; 4 - Good; 5 - Very good.

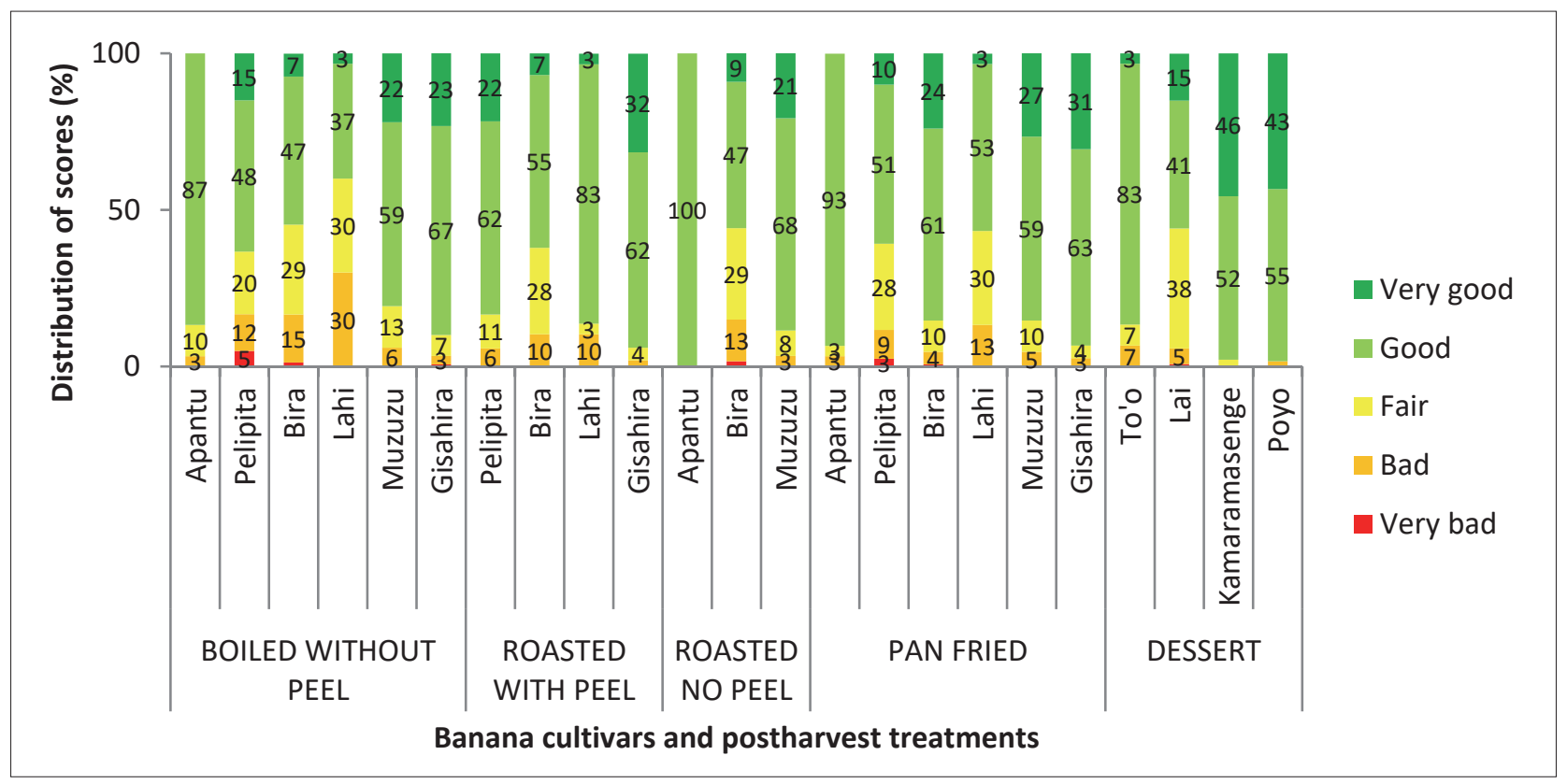

FIGURE 1. Distribution of overall acceptability scores by panellists based on different banana postharvest treatments in Burundi $(N=150)$. 


\section{Scoring method}

A panel of farmers, including 50\% males and 50\% females, evaluated the prepared samples. At each of the three sites, sensory evaluation was carried out in two separate exercises. This, together with the availability of banana samples at each of the evaluation exercises, influenced the sample size for each cultivar and the respective processing methods. At the end of the two exercises, sample sizes ranged from 29 to 150 (Tables 4, 6 and 8). The attributes of interest included: pulp-appearance, aroma, texture in hand, texture in mouth, taste, and overall acceptability. For the unpeeled dessert samples peel appearance and ease of peeling were also evaluated. Attributes were scored on a hedonic scale of 1 to 5 ( 1 =very bad, 2 =bad, $3=$ fair, 4 =good, $5=$ very good). The panellists evaluated all samples prepared using the same post-harvest treatment at the same time, before proceeding to those of a different treatment. The panellists rinsed their mouths between samples.

\section{Statistical analysis}

SPSS version 16.0 (Statistical Package for Social Sciences, USA) was used to generate descriptive statistics (means, median, percentage distributions). The Pearson correlation coefficient was used to test the relationship between the scores of the different sensory attributes and the scores for overall acceptability. ANOVA using Genstat version 13 (VSN International Ltd., UK) was used to test the differences in the sensory attributes of the different cultivars and the Least Significant Difference (LSD) was used to separate means. The level of significance was accepted at $P<0.05$.

\section{Results and discussion}

\section{Burundi}

\section{Boiled without peel}

The mean overall performance of the cultivars boiled without peel was rated between fair and good (Table 4). 'Apantu', 'Muzuzu' and 'Gisahira' were rated as acceptable (good or very good) by $>80 \%$ of the participants (Figure 1). 'Pelipita' and 'Bira' were also acceptable to $>50 \%$ of respondents. 'Apantu', 'Muzuzu' and 'Gisahira' received the highest scores for overall acceptability (Table 4). 'Gisahira' was rated significantly higher than all other cultivars for aroma. 'Muzuzu' and 'Gisahira' received the highest scores for pulp appearance and texture in hand and mouth. 'Gisahira', 'Muzuzu' and 'Apantu' received the highest scores for taste. The mean score for pulp appearance of 'Muzuzu' given by male respondents was significantly higher than that given by females. On the other hand, the mean scores by females were significantly higher than those by males for texture in mouth and taste of 'Gisahira'. Pulp appearance, aroma, texture in hand, texture in mouth and taste showed a significant positive correlation with overall acceptability for all cultivars (Table 5).

\section{Roasted with peel}

The mean overall performance of the cultivars roasted with peel was rated good (Table 4). 'Lahi', 'Pelipita' and 'Gisahira' were rated as acceptable by more than $80 \%$ of the participants (Figure 1). 'Bira' was also acceptable to $>50 \%$ of

TABLE 5. Correlation coefficients between sensory attribute scores and the overall acceptability scores of local (L) and introduced (I) banana cultivars in Burundi.

\begin{tabular}{|c|c|c|c|c|c|c|c|c|c|}
\hline $\begin{array}{l}\text { Postharvest } \\
\text { treatments }\end{array}$ & Cultivars & $N$ & $\begin{array}{c}\text { Peel } \\
\text { appearance }\end{array}$ & $\begin{array}{l}\text { Ease of } \\
\text { peeling }\end{array}$ & $\begin{array}{c}\text { Pulp } \\
\text { appearance }\end{array}$ & Aroma & $\begin{array}{l}\text { Texture } \\
\text { in hand }\end{array}$ & $\begin{array}{l}\text { Texture } \\
\text { in mouth }\end{array}$ & Taste \\
\hline \multirow{6}{*}{$\begin{array}{l}\text { Boiled } \\
\text { without peel }\end{array}$} & 'Apantu' (I) & 30 & & & $0.44^{*}$ & $0.47^{*}$ & $0.49^{*}$ & $0.56^{*}$ & $0.44^{*}$ \\
\hline & 'Bira' (I) & 150 & & & $0.64^{*}$ & $0.71^{*}$ & $0.70^{*}$ & $0.74^{*}$ & $0.65^{\star}$ \\
\hline & 'Lahi' (I) & 30 & & & $0.45^{*}$ & $0.64^{*}$ & $0.77^{*}$ & $0.93^{*}$ & $0.86^{*}$ \\
\hline & 'Pelipita' (I) & 120 & & & $0.55^{*}$ & $0.68^{*}$ & $0.75^{*}$ & $0.85^{\star}$ & $0.86^{*}$ \\
\hline & 'Muzuzu' (L) & 150 & & & $0.50^{*}$ & $0.56^{*}$ & $0.70^{*}$ & $0.77^{*}$ & $0.76^{*}$ \\
\hline & 'Gisahira' (L) & 150 & & & $0.67^{*}$ & $0.62^{*}$ & $0.75^{\star}$ & $0.71^{*}$ & $0.71^{*}$ \\
\hline \multirow{4}{*}{$\begin{array}{l}\text { Roasted } \\
\text { with peel }\end{array}$} & 'Bira' (I) & 29 & & & 0.10 & 0.14 & -0.17 & -0.12 & 0.00 \\
\hline & 'Lahi' (I) & 29 & & & $0.58^{*}$ & $0.38^{*}$ & 0.29 & $0.76^{*}$ & $0.63^{*}$ \\
\hline & ‘Pelipita' (I) & 120 & & & $0.70^{*}$ & $0.73^{*}$ & $0.51^{*}$ & $0.74^{*}$ & $0.79^{*}$ \\
\hline & 'Gisahira' (L) & 149 & & & $0.60^{*}$ & $0.55^{\star}$ & $0.53^{*}$ & 0.10 & $0.61^{*}$ \\
\hline \multirow{2}{*}{$\begin{array}{l}\text { Roasted } \\
\text { without peel }\end{array}$} & 'Bira' (I) & 149 & & & $0.56^{*}$ & $0.55^{*}$ & $0.54^{*}$ & $0.67^{\star}$ & $0.69^{*}$ \\
\hline & 'Muzuzu' (L) & 149 & & & $0.63^{*}$ & $0.63^{*}$ & $0.61^{*}$ & $0.80^{*}$ & $0.70^{*}$ \\
\hline \multirow{6}{*}{ Pan-fried } & 'Apantu' (I) & 30 & & & $0.55^{*}$ & $0.49^{*}$ & $0.49^{*}$ & $0.58^{\star}$ & $0.41^{*}$ \\
\hline & 'Bira' (I) & 150 & & & $0.40^{*}$ & $0.73^{*}$ & $0.66^{*}$ & $0.81^{*}$ & $0.79^{*}$ \\
\hline & 'Lahi' (I) & 150 & & & $0.49^{*}$ & $0.60^{*}$ & $0.74^{*}$ & $0.71^{*}$ & $0.66^{*}$ \\
\hline & 'Pelipita' (I) & 120 & & & $0.56^{*}$ & $0.70^{*}$ & $0.67^{*}$ & $0.78^{*}$ & $0.80^{*}$ \\
\hline & ‘Muzuzu' (L) & 150 & & & $0.49^{*}$ & $0.60^{*}$ & $0.74^{*}$ & $0.71^{*}$ & $0.66^{*}$ \\
\hline & 'Gisahira' (L) & 150 & & & $0.64^{*}$ & $0.75^{\star}$ & $0.62^{*}$ & $0.80^{*}$ & $0.77^{\star}$ \\
\hline \multirow{4}{*}{ Dessert } & 'To'o' (I) & 30 & -0.17 & -0.33 & 0.27 & & 0.31 & $0.47^{*}$ & $0.54^{*}$ \\
\hline & ‘Laï' (I) & 120 & $0.48^{*}$ & $0.50^{*}$ & $0.61^{*}$ & & $0.66^{*}$ & $0.80^{*}$ & $0.83^{*}$ \\
\hline & 'Kamaramasenge' (L) & 90 & $0.33^{*}$ & $0.60^{*}$ & $0.39^{*}$ & & $0.69^{*}$ & $0.64^{*}$ & $0.47^{*}$ \\
\hline & 'Poyo' (L) & 60 & $0.55^{*}$ & $0.55^{*}$ & $0.54^{*}$ & & $0.70^{*}$ & $0.82^{*}$ & $0.73^{*}$ \\
\hline
\end{tabular}

${ }^{*}$ Correlation coefficients between the different sensory attributes and the overall acceptability per postharvest treatment per banana cultivar (across rows) are statistically significant $(P<0.05)$

$N=$ number of banana samples.

Evaluation scale: 1 - Very bad; 2 - Bad; 3 - Fair; 4 - Good; 5 - Very good. 
respondents. 'Gisahira' and 'Lahi' received the highest scores for overall acceptability (Table 4). 'Gisahira' was rated significantly higher than the other cultivars for pulp appearance. 'Pelipita' and 'Gisahira' received the highest scores for aroma and texture in hand. 'Lahi', 'Pelipita' and 'Gisahira' scored best for texture in mouth and taste. There was no significant difference between the mean scores by male participants and those by female participants for all the sensory attributes. With some exceptions, pulp appearance, aroma, texture in hand, texture in mouth and taste showed a significant positive correlation with overall acceptability for all cultivars except 'Bira' (Table 5).

\section{Roasted without peel}

The mean overall performance of the cultivars roasted without peel was rated between fair and very good (Table 4). 'Apantu' was rated as good by $100 \%$ of participants (Figure 1). 'Muzuzu' was rated as acceptable by more than $80 \%$ of the participants (Table 4). 'Bira' was also acceptable to $>50 \%$ of respondents. 'Apantu' and 'Muzuzu' received the highest scores for overall acceptability and all individual sensory attributes (Table 4). There was no significant difference between the mean scores given by males and those given by females with regards to 'Apantu' and 'Bira'. The male participants had a significantly higher mean score for taste of 'Muzuzu' compared to the females. Pulp appearance, aroma, texture in hand, texture in mouth and taste showed a significant positive correlation with overall acceptability for all cultivars (Table 5).

\section{Pan-fried}

The mean overall performance of the pan-fried cultivars was rated between fair and very good (Table 4). 'Apantu', 'Bira', 'Muzuzu' and 'Gisahira' were rated as acceptable by $>80 \%$ of the participants (Figure 1). 'Pelipita' and 'Lahi' were also acceptable to $>50 \%$ of respondents. 'Gisahira' received the highest score for overall acceptability (Table 4). 'Bira' and 'Gisahira' scored highest for pulp appearance. 'Bira', 'Lahi', 'Muzuzu' and 'Gisahira' received the highest scores for aroma. 'Apantu', 'Bira', 'Muzuzu' and 'Gisahira' scored highest for

TABLE 6. Mean scores for the sensory attributes of local (L) and introduced (I) banana cultivars following different postharvest treatments in North Kivu, Democratic Republic of Congo.

\begin{tabular}{|c|c|c|c|c|c|c|c|c|c|c|}
\hline $\begin{array}{l}\text { Postharvest } \\
\text { treatments }\end{array}$ & Cultivars & $N$ & $\begin{array}{c}\text { Peel } \\
\text { appearance }\end{array}$ & $\begin{array}{l}\text { Ease of } \\
\text { peeling }\end{array}$ & $\begin{array}{c}\text { Pulp } \\
\text { appearance }\end{array}$ & Aroma & $\begin{array}{l}\text { Texture } \\
\text { in hand }\end{array}$ & $\begin{array}{l}\text { Texture } \\
\text { in mouth }\end{array}$ & Taste & $\begin{array}{c}\text { Overall } \\
\text { acceptability }\end{array}$ \\
\hline \multirow{8}{*}{$\begin{array}{l}\text { Boiled } \\
\text { without peel }\end{array}$} & 'Apantu' (I) & 150 & & & $3.89 b$ & $4.05^{b}$ & $3.83^{b}$ & $3.95^{c}$ & $4.03^{c}$ & $4.01 c$ \\
\hline & 'Pelipita' (I) & 120 & & & $3.15^{\mathrm{a}}$ & $3.33^{a}$ & $3.23 a$ & $2.94 a$ & $2.92^{\mathrm{a}}$ & $3.00 \mathrm{a}$ \\
\hline & 'Bira' (I) & 150 & & & $4.11 \mathrm{c}$ & $4.07 \mathrm{bc}$ & $3.80^{b}$ & $3.71 \mathrm{~b}$ & $3.63^{b}$ & $3.76^{b}$ \\
\hline & 'Lahi' (I) & 60 & & & $4.0 \mathrm{~b}, \mathrm{c}$ & $4.02^{b c}$ & $3.73^{b}$ & $3.88^{b, c}$ & $3.95 c$ & $3.98 b, c$ \\
\hline & 'Hung Tu' (I) & 30 & & & $3.03^{a}$ & $3.10^{\mathrm{a}}$ & $3.07^{a}$ & $3.00 \mathrm{a}$ & $2.83^{a}$ & $3.00 \mathrm{a}$ \\
\hline & 'Musilongo' (L) & 150 & & & $4.17 \mathrm{c}$ & $4.23 c d$ & $4.04 c$ & $4.25^{d}$ & $4.33^{d}$ & $4.33^{d}$ \\
\hline & 'Vulambya' (L) & 120 & & & $4.44 \mathrm{~d}$ & $4.42^{\mathrm{d}}$ & $4.26^{d}$ & $4.32^{\mathrm{d}}$ & $4.49 \mathrm{~d}$ & $4.43^{d}$ \\
\hline & LSD & & & & 0.38 & 0.34 & 0.36 & 0.37 & 0.38 & 0.37 \\
\hline \multirow{3}{*}{$\begin{array}{l}\text { Roasted } \\
\text { with peel }\end{array}$} & 'Lahi' (I) & 30 & & & $4.53^{a}$ & $4.17 \mathrm{a}$ & $4.07 a$ & $4.47 \mathrm{a}$ & $4.53^{a}$ & $4.60^{a}$ \\
\hline & 'Vulambya' (L) & 120 & & & $4.32^{\mathrm{a}}$ & $4.38^{a}$ & $4.08^{a}$ & $4.33^{a}$ & $4.58^{\mathrm{a}}$ & $4.55^{\mathrm{a}}$ \\
\hline & LSD & & & & 0.33 & - & - & - & - & - \\
\hline \multirow{7}{*}{$\begin{array}{l}\text { Roasted } \\
\text { without peel }\end{array}$} & 'Apantu' (I) & 120 & & & $4.27 c$ & $4.33^{c}$ & $3.99 \mathrm{bc}$ & $4.09 c d$ & $4.33 c$ & $4.26^{c}$ \\
\hline & 'Pelipita' (I) & 90 & & & $3.11 \mathrm{a}$ & $3.46^{\mathrm{a}}$ & $3.02^{\mathrm{a}}$ & $3.13^{b}$ & $3.14^{a}$ & $3.10^{a}$ \\
\hline & 'Bira' (I) & 120 & & & $3.68^{b}$ & $3.89^{b}$ & $3.67 \mathrm{~b}$ & $3.55^{b}$ & $3.50^{b}$ & $3.56^{b}$ \\
\hline & 'Lahi' (I) & 30 & & & $3.60^{b}$ & $3.83^{b}$ & $4.00 c$ & $3.83^{b c}$ & $3.70^{b}$ & $3.83^{\mathrm{b}}$ \\
\hline & 'Hung Tu' (I) & 30 & & & $2.80^{a}$ & $3.33^{a}$ & $2.97^{a}$ & $2.73^{a}$ & $2.93^{a}$ & $2.87^{a}$ \\
\hline & 'Musilongo' (L) & 120 & & & $4.47 \mathrm{c}$ & $4.42^{c}$ & $4.21 \mathrm{c}$ & $4.42^{\mathrm{d}}$ & $4.57 \mathrm{c}$ & $4.46^{c}$ \\
\hline & LSD & & & & 0.32 & 0.31 & 0.32 & 0.32 & 0.32 & 0.30 \\
\hline \multirow{7}{*}{ Pan-fried } & 'Apantu' (I) & 120 & & & $4.00^{b}$ & $4.23 c$ & $3.86^{b}$ & $4.00^{b}$ & $4.15^{b}$ & $4.09 b$ \\
\hline & 'Pelipita' (I) & 90 & & & $2.71^{\mathrm{a}}$ & $3.34^{a}$ & $2.82^{\mathrm{a}}$ & $2.68^{a}$ & $2.66^{\mathrm{a}}$ & $2.77^{a}$ \\
\hline & 'Bira' (I) & 120 & & & $4.43 c$ & $4.22 c$ & $4.03^{b}$ & $3.92^{b}$ & $3.61^{b}$ & $3.83^{b}$ \\
\hline & 'Lahi' (I) & 30 & & & $3.90^{b}$ & $3.83^{b}$ & $3.70_{\mathrm{ab}}$ & $3.70^{b}$ & $3.97 \mathrm{~b}$ & $4.00^{b}$ \\
\hline & 'Hung Tu' (I) & 30 & & & $3.00^{a}$ & $3.43^{a}$ & $2.93^{a}$ & $2.77^{a}$ & $2.77^{a}$ & $2.73^{a}$ \\
\hline & 'Musilongo' (L) & 120 & & & $4.44 c$ & $4.44 c$ & $4.61 \mathrm{c}$ & $4.28 c$ & $4.51 \mathrm{c}$ & $4.47 \mathrm{c}$ \\
\hline & $\mathrm{LSD}$ & & & & 0.34 & 0.28 & 0.88 & 0.33 & 0.35 & 0.32 \\
\hline \multirow{6}{*}{ Dessert } & 'Sepi' (I) & 30 & $2.93^{a}$ & $2.73^{a}$ & $3.17 \mathrm{a}$ & & $2.97 a$ & $3.07 a$ & $3.00^{a}$ & $3.13^{a}$ \\
\hline & 'To'o' (I) & 30 & $3.79^{b}$ & $3.85^{c}$ & $3.83^{b}$ & & $3.64^{b}$ & $3.49^{b}$ & $3.51^{b}$ & $3.60^{b}$ \\
\hline & 'Laï' (I) & 90 & $3.74 b$ & $3.41 \mathrm{~b}$ & $4.44 c$ & & $4.40 c$ & $4.30 c$ & $4.39 c$ & $4.26 c$ \\
\hline & 'Kamaramasenge' (L) & 120 & $4.56 c$ & $4.62^{d}$ & $4.54 c$ & & $4.55^{c}$ & $4.58 \mathrm{c}$ & $4.71 \mathrm{~d}$ & $4.60 \mathrm{~d}$ \\
\hline & 'Kitika Sukari' (L) & 90 & $4.53 c$ & $4.40 \mathrm{~d}$ & $4.39 c$ & & $4.37 c$ & $4.37 \mathrm{c}$ & $4.41 \mathrm{c}$ & $4.36 \mathrm{~cd}$ \\
\hline & LSD & & 0.28 & 0.31 & 0.31 & & 0.31 & 0.31 & 0.16 & 0.30 \\
\hline
\end{tabular}

Means in the same column under the same postharvest treatment followed by the same letter are not significantly different $(P<0.05)$. $N=$ number of banana samples.

Evaluation scale: 1 - Very bad; 2 - Bad; 3 - Fair; 4 - Good; 5 - Very good. 
texture in hand. 'Muzuzu' and 'Gisahira' received the highest scores for texture in mouth and taste. The male participants had significantly higher mean scores for texture in hand of 'Apantu' and aroma of 'Bira'. On the other hand, female participants had significantly higher mean scores for texture in hand of 'Pelipita'. There was no significant difference between the preference mean scores by the male and female participants for pan-fried 'Lahi', 'Muzuzu' and 'Gisahira'. Pulp appearance, aroma, texture in hand, texture in mouth and taste showed a significant positive correlation with overall acceptability for all cultivars (Table 5).

\section{Dessert}

The mean overall performance of the dessert cultivars roasted without peel was rated good (Table 4). 'To'o', 'Kamaramasenge' and 'Poyo' were rated as acceptable by $>80 \%$ of the participants (Figure 1). 'Laï' was also acceptable to $>50 \%$ of respondents. 'Kamaramasenge' and 'Poyo' received the highest scores for overall acceptability, and also for ease of peeling, texture in hand and mouth, and taste (Table 4). 'Kamaramasenge' scored highest for peel appearance. No differences were observed between the cultivars for pulp appearance. No significant differences were observed between the mean scores from male and female panellists, except for a significantly higher mean score for overall acceptability of
'Kamaramasenge' and pulp appearance of 'Laï' from males compared to females. A significant positive correlation was observed between the scores of all the sensory attributes and the overall acceptability score for 'Laï', 'Kamaramasenge' and 'Poyo' (Table 5). For 'To'o', only texture in mouth and taste were significantly positively correlated with overall acceptability.

\section{North Kivu}

\section{Boiled without peel}

The mean overall performance of the cultivars boiled without peel was rated between fair and good (Table 6). 'Vulambya', 'Musilongo' and 'Lahi' were rated as acceptable (good or very good) by $>80 \%$ of the participants (Figure 2). 'Bira' and 'Apantu' were also acceptable to $>50 \%$ of respondents. 'Vulambya' received the highest scores for all sensory attributes (Table 6). 'Musilongo' also received top scores for overall acceptability, texture in hand and aroma. 'Apantu' also scored well on all sensory attributes, as did 'Bira' for pulp appearance, aroma and texture in hand. Only 'Bira' and 'Pelipita' showed a significant difference between the mean scores given by the male and female panellists with the males having significantly higher mean scores with regards to pulp appearance, texture (in the hand for 'Bira'

TABLE 7. Correlation coefficients between sensory attribute scores and the overall acceptability scores of local (L) and introduced (I) banana cultivars in North Kivu, Democratic Republic of Congo.

\begin{tabular}{|c|c|c|c|c|c|c|c|c|c|}
\hline $\begin{array}{l}\text { Postharvest } \\
\text { treatments }\end{array}$ & Cultivars & $N$ & $\begin{array}{c}\text { Peel } \\
\text { appearance }\end{array}$ & $\begin{array}{l}\text { Ease of } \\
\text { peeling }\end{array}$ & $\begin{array}{c}\text { Pulp } \\
\text { appearance }\end{array}$ & Aroma & $\begin{array}{l}\text { Texture } \\
\text { in hand }\end{array}$ & $\begin{array}{c}\text { Texture } \\
\text { in mouth }\end{array}$ & Taste \\
\hline \multirow{7}{*}{$\begin{array}{l}\text { Boiled } \\
\text { without peel }\end{array}$} & 'Apantu' (I) & 150 & & & $0.63^{*}$ & $0.53^{*}$ & $0.61^{*}$ & $0.85^{*}$ & $0.84^{*}$ \\
\hline & 'Bira' (I) & 150 & & & $0.43^{*}$ & $0.41^{*}$ & $0.60^{*}$ & $0.77^{*}$ & $0.85^{*}$ \\
\hline & 'Lahi' (I) & 60 & & & $0.30^{*}$ & $0.31^{*}$ & $0.39^{*}$ & $0.59^{*}$ & $0.81^{*}$ \\
\hline & 'Pelipita' (I) & 120 & & & $0.64^{*}$ & $0.58^{*}$ & $0.61^{*}$ & $0.84^{*}$ & $0.87^{*}$ \\
\hline & 'Hung Tu' (I) & 30 & & & $0.55^{*}$ & $0.53^{*}$ & $0.36^{*}$ & $0.81^{*}$ & $0.86^{*}$ \\
\hline & 'Musilongo' (L) & 150 & & & $0.58^{*}$ & $0.48^{*}$ & $0.57^{*}$ & $0.82^{*}$ & $0.87^{*}$ \\
\hline & 'Vulambya' (L) & 120 & & & $0.52^{*}$ & $0.43^{*}$ & $0.51^{*}$ & $0.72^{*}$ & $0.80^{*}$ \\
\hline \multirow{2}{*}{$\begin{array}{l}\text { Roasted } \\
\text { with peel }\end{array}$} & 'Lahi' (I) & 30 & & & $0.50^{*}$ & -0.35 & $-0.22^{*}$ & $0.68^{*}$ & $0.90^{*}$ \\
\hline & 'Vulambya' (L) & 120 & & & $0.55^{\star}$ & $0.36^{*}$ & $0.52^{*}$ & $0.63^{*}$ & $0.81^{*}$ \\
\hline \multirow{6}{*}{$\begin{array}{l}\text { Roasted } \\
\text { without peel }\end{array}$} & 'Apantu' (I) & 120 & & & $0.30^{*}$ & $0.49^{*}$ & $0.45^{\star}$ & $0.59^{*}$ & $0.74^{*}$ \\
\hline & 'Bira' (I) & 120 & & & $0.56^{*}$ & $0.31^{*}$ & $0.62^{*}$ & $0.72^{*}$ & $0.78^{*}$ \\
\hline & 'Lahi' (I) & 30 & & & $0.51^{*}$ & $0.63^{*}$ & $0.61^{*}$ & $0.42^{*}$ & $0.55^{*}$ \\
\hline & 'Hung Tu' (I) & 30 & & & $0.70^{*}$ & $0.52^{*}$ & $0.61^{*}$ & $0.83^{*}$ & $0.61^{*}$ \\
\hline & 'Pelipita' (I) & 90 & & & $0.55^{*}$ & $0.52^{*}$ & $0.26^{*}$ & $0.72^{*}$ & $0.89^{*}$ \\
\hline & 'Musilongo' (L) & 120 & & & $0.33^{*}$ & $0.41^{*}$ & $0.34^{*}$ & $0.60^{*}$ & $0.77^{*}$ \\
\hline \multirow{6}{*}{ Pan-fried } & 'Apantu' (I) & 120 & & & $0.47^{*}$ & $0.65^{*}$ & $0.68^{*}$ & $0.78^{*}$ & $0.81^{*}$ \\
\hline & 'Bira' (I) & 120 & & & $0.25^{\star}$ & $0.34^{*}$ & $0.46^{*}$ & $0.69^{*}$ & $0.85^{*}$ \\
\hline & 'Lahi' (I) & 30 & & & $0.45^{\star}$ & 0.29 & $0.48^{*}$ & $0.61^{*}$ & $0.57^{*}$ \\
\hline & 'Hung Tu' (I) & 30 & & & 0.15 & $0.51^{*}$ & $0.56^{*}$ & $0.81^{*}$ & $0.89^{*}$ \\
\hline & 'Pelipita' (I) & 90 & & & $0.55^{\star}$ & $0.40^{*}$ & $0.51^{*}$ & $0.67^{*}$ & $0.86^{*}$ \\
\hline & 'Musilongo' (L) & 120 & & & $0.38^{*}$ & $0.33^{*}$ & 0.13 & $0.55^{*}$ & $0.71^{*}$ \\
\hline \multirow{5}{*}{ Dessert } & 'Sepi' (I) & 30 & $0.41^{*}$ & 0.35 & 0.23 & 0.24 & $0.47^{*}$ & $0.79^{*}$ & $0.75^{\star}$ \\
\hline & 'To'o' (I) & 30 & $0.41^{*}$ & 0.35 & 0.23 & 0.24 & $0.47^{*}$ & $0.79^{*}$ & $0.75^{\star}$ \\
\hline & 'Laï' (I) & 90 & 0.12 & 0.12 & $0.28^{*}$ & $0.29^{*}$ & 0.18 & $0.63^{*}$ & $0.73^{*}$ \\
\hline & 'Kamaramasenge' (L) & 120 & $0.23^{*}$ & $0.42^{*}$ & $0.40^{*}$ & 0.18 & $0.55^{\star}$ & $0.66^{*}$ & $0.53^{*}$ \\
\hline & 'Kitika Sukari' (L) & 90 & $0.39^{*}$ & $0.44^{*}$ & $0.53^{*}$ & - & $0.55^{*}$ & $0.67^{*}$ & $0.76^{*}$ \\
\hline
\end{tabular}

* Correlation coefficients between the different sensory attributes and the overall acceptability per postharvest treatment per banana cultivar (across rows) are statistically significant $(P<0.05)$.

$N=$ number of banana samples.

Evaluation scale: 1 - Very bad; 2 - Bad; 3 - Fair; 4 - Good; 5 - Very good. 


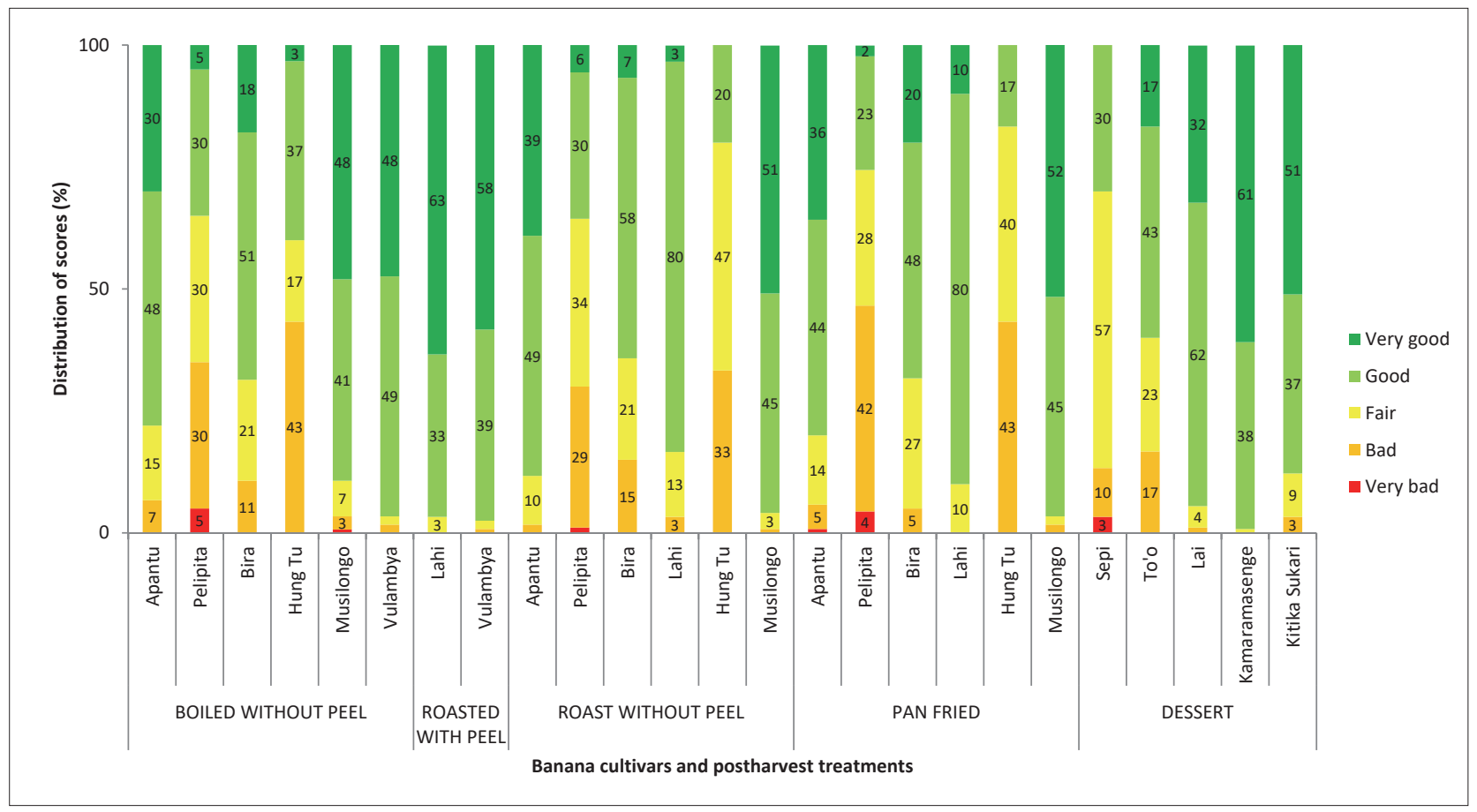

FIGURE 2. Distribution of overall acceptability scores by panellists based on different banana postharvest treatments in North Kivu, Democratic Republic of Congo $(N=150)$.

TABLE 8. Mean scores for the sensory attributes of local (L) and introduced (I) banana cultivars following different postharvest treatments in South Kivu, Democratic Republic of Congo.

\begin{tabular}{|c|c|c|c|c|c|c|c|c|c|c|}
\hline $\begin{array}{l}\text { Postharvest } \\
\text { treatments }\end{array}$ & Cultivars & $N$ & $\begin{array}{c}\text { Peel } \\
\text { appearance }\end{array}$ & $\begin{array}{l}\text { Ease of } \\
\text { peeling }\end{array}$ & $\begin{array}{c}\text { Pulp } \\
\text { appearance }\end{array}$ & Aroma & $\begin{array}{l}\text { Texture } \\
\text { in hand }\end{array}$ & $\begin{array}{l}\text { Texture } \\
\text { in mouth }\end{array}$ & Taste & $\begin{array}{c}\text { Overall } \\
\text { acceptability }\end{array}$ \\
\hline \multirow{7}{*}{$\begin{array}{l}\text { Boiled } \\
\text { without peel }\end{array}$} & 'Apantu' (I) & 150 & & & $3.92^{b}$ & $4.07 \mathrm{bc}$ & $3.70^{b}$ & $3.92^{b c}$ & $3.97 c$ & $4.01 c$ \\
\hline & ‘Pelipita' (I) & 150 & & & $3.56^{a}$ & $3.65^{a}$ & $3.07 a$ & $3.34 a$ & $3.47 \mathrm{a}$ & $3.55^{\mathrm{a}}$ \\
\hline & 'Bira' (I) & 90 & & & $3.84 b$ & $4.13 c$ & $3.93 c$ & $3.78^{b}$ & $3.57 a b$ & $3.70 \mathrm{ab}$ \\
\hline & 'Lahi' (I) & 150 & & & $3.94 b$ & $4.27^{\mathrm{cd}}$ & $3.78^{b}$ & $3.77 c$ & $3.71^{b}$ & $3.87 \mathrm{a}$ \\
\hline & 'Musheba' (L) & 150 & & & $3.84 b$ & $3.89 \mathrm{~b}$ & $3.73^{b}$ & $4.00 c$ & $3.98 c$ & $3.99 c$ \\
\hline & 'Barhebesha' (L) & 150 & & & $4.21 \mathrm{c}$ & $4.35^{d}$ & $4.26^{d}$ & $4.29 \mathrm{~d}$ & $4.30 \mathrm{~d}$ & $4.37 \mathrm{~d}$ \\
\hline & LSD & & & & 0.19 & 0.20 & 0.19 & 0.20 & 0.21 & 0.21 \\
\hline \multirow{4}{*}{$\begin{array}{l}\text { Roasted } \\
\text { without peel }\end{array}$} & 'Apantu' (I) & 150 & & & $3.92^{\mathrm{ab}}$ & $3.99 \mathrm{a}$ & $3.71^{a}$ & $3.92^{b}$ & $3.97 \mathrm{~b}$ & $4.07^{b}$ \\
\hline & 'Bira' (I) & 90 & & & $3.73^{a}$ & $3.87 \mathrm{a}$ & $3.51 \mathrm{a}$ & $3.41 \mathrm{a}$ & $3.50 \mathrm{a}$ & $3.60 \mathrm{a}$ \\
\hline & 'Musheba' (L) & 150 & & & $4.03^{b}$ & $3.87 \mathrm{a}$ & $3.73^{a}$ & $3.97 \mathrm{~b}$ & $4.03^{b}$ & $4.09 \mathrm{~b}$ \\
\hline & LSD & & & & 0.19 & 0.20 & 0.20 & 0.21 & 0.22 & 0.21 \\
\hline \multirow{4}{*}{ Pan-fried } & 'Apantu' (I) & 150 & & & $4.17^{b}$ & $4.14^{a}$ & $3.92^{\mathrm{a}}$ & $4.17^{b}$ & $4.19 b$ & $4.21^{b}$ \\
\hline & 'Bira' (I) & 90 & & & $3.94 a$ & $4.18 \mathrm{a}$ & $3.76^{a}$ & $3.72^{a}$ & $3.84 a$ & $3.92^{\mathrm{a}}$ \\
\hline & 'Musheba' (L) & 150 & & & $4.17 \mathrm{~b}$ & $4.11 \mathrm{a}$ & $3.72^{\mathrm{a}}$ & $4.08^{b}$ & $4.25^{b}$ & $4.24 \mathrm{~b}$ \\
\hline & LSD & & & & 0.17 & 0.19 & 0.21 & 0.11 & 0.10 & 0.11 \\
\hline \multirow{4}{*}{ Dessert } & 'To'o' (I) & 60 & $3.43^{a}$ & $3.28 \mathrm{a}$ & $2.95^{a}$ & $3.50 \mathrm{a}$ & $3.02^{a}$ & $2.85^{a}$ & $2.80^{a}$ & $3.02^{a}$ \\
\hline & 'Laï' (I) & 149 & $3.71 \mathrm{~b}$ & $3.41 \mathrm{a}$ & $3.72^{b}$ & $3.80^{b}$ & $3.48^{b}$ & $3.58^{b}$ & $3.73^{b}$ & $3.72^{b}$ \\
\hline & ‘Gros Michel' (L) & 150 & $4.53^{c}$ & $4.44 \mathrm{~b}$ & $4.41 \mathrm{c}$ & $4.45^{c}$ & $4.33^{c}$ & $4.55^{c}$ & $4.59 c$ & $4.63^{c}$ \\
\hline & LSD & & 0.22 & 0.12 & 0.11 & 0.11 & 0.13 & 0.21 & 0.22 & 0.22 \\
\hline
\end{tabular}

Means in the same column under the same post-harvest treatment followed by the same letter are not significantly different $(P<0.05)$. $N=$ number of banana samples.

Evaluation scale: 1 - Very bad; 2 - Bad; 3 - Fair; 4 - Good; 5 - Very good. 


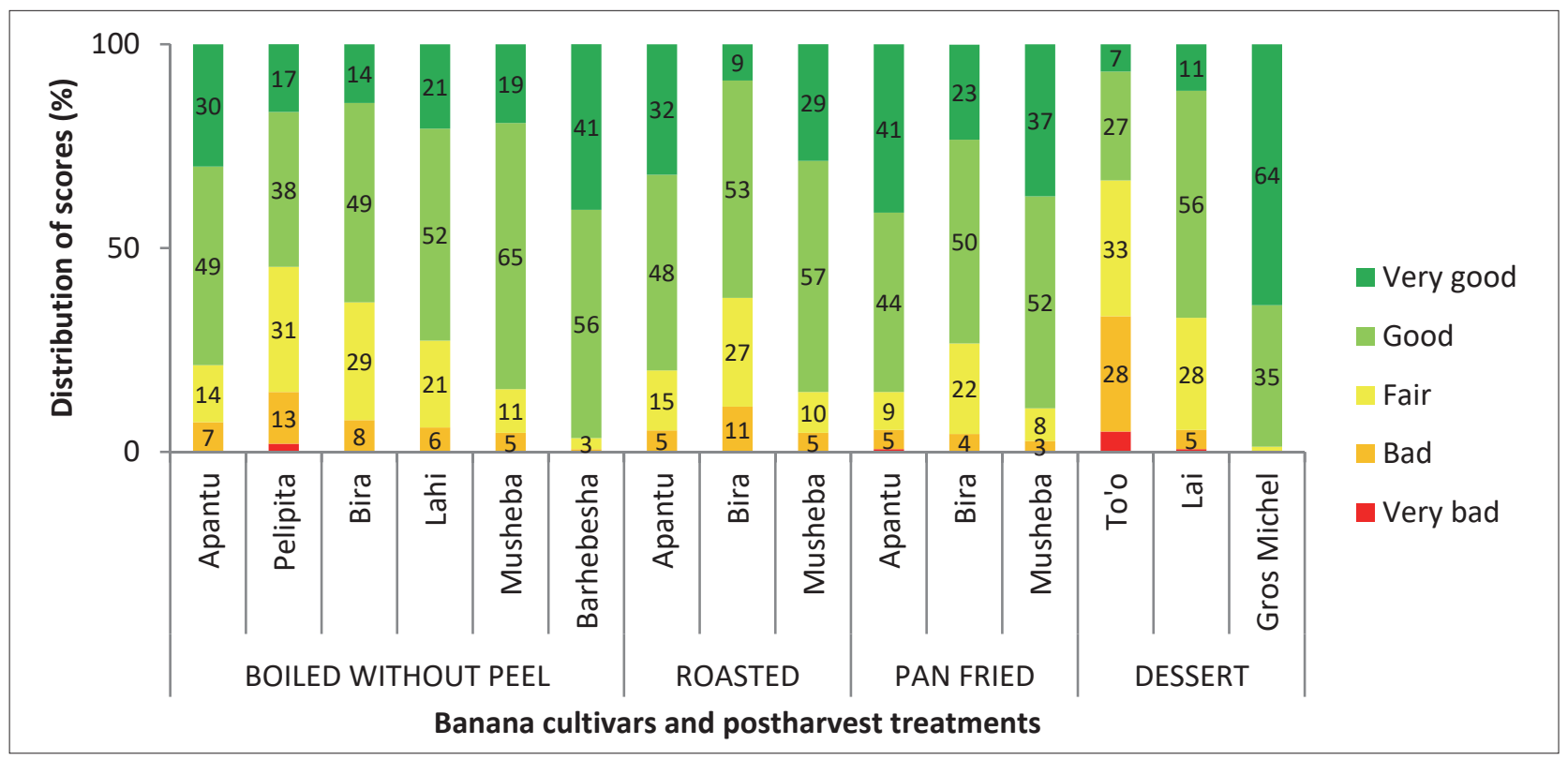

FIGURE 3. Distribution of overall evaluation scores by panellists based on different banana postharvest treatments in South Kivu, Democratic Republic of Congo $(N=150)$.

and in the mouth for 'Pelipita'), taste (for 'Pelipita') and overall acceptability. A significant positive correlation was observed for all sensory attributes and overall evaluation for all the cultivars boiled without peel (Table 7).

\section{Roasted with peel}

After roasting with peel, both 'Lahi' and 'Vulambya' were rated very good (Table 6). Both were rated as acceptable (good or very good) by $>95 \%$ of the participants (Figure 2 ). There was no significant difference between the mean scores of 'Lahi' and 'Vulambya' for any of the sensory attributes, except for peel appearance ('Lahi' scored better) and ease of peeling ('Vulambya' scored better) (Table 6). 'Lahi' showed no significant difference between the mean scores by the male and female panellists for any of the sensory attributes, while 'Vulambya' showed significantly higher scores for overall acceptability among the males. Both 'Lahi' and 'Vulambya' showed a significant positive correlation between the scores for pulp appearance, texture in mouth and taste, and overall acceptability (Table 7).

\section{Roasted without peel}

The mean overall performance of the cultivars roasted without peel was rated between fair and good (Table 6). More than $80 \%$ of the panellists rated roasted 'Musilongo', 'Lahi' and 'Apantu' as acceptable (good or very good) (Figure 2). 'Bira' and 'Hung Tu' were also acceptable to $>50 \%$ of respondents. 'Musilongo' and 'Apantu' received the highest scores for all sensory attributes and overall acceptability (Table 6). 'Lahi' also scored well for texture in hand. 'Bira' and 'Pelipita' showed a significant difference between the mean scores by male and female panellists with higher male scores for pulp appearance ('Pelipita'), texture in the mouth ('Bira'), and overall acceptability ('Bira'). On the other hand, female panellists gave 'Lahi' significantly higher scores than the males for taste. For all cultivars, there was a significant correlation between the scores for the different sensory attributes and the scores for overall acceptability (Table 7).

\section{Pan-fried}

The mean overall performance of the pan-fried cultivars was rated between fair and good (Table 6). 'Musilongo', 'Apantu' and 'Lahi' were rated as acceptable (good or very good) by $>80 \%$ of the participants (Figure 2). 'Bira' was also acceptable to $>50 \%$ of respondents. 'Musilongo' received the highest scores for texture in hand, texture in mouth, taste and overall acceptability (Table 6). 'Bira' and 'Musilongo' scored highest for pulp appearance, and both of them plus 'Apantu' received the highest scores for aroma. For all cultivars, there was no significant difference between the mean scores of the male and female panellists. All sensory attributes showed a significant positive correlation with overall acceptability for all cultivars, except pulp appearance for 'Hung Tu', aroma for 'Lahi' and texture in hand for 'Musilongo' (Table 7).

\section{Dessert}

The mean overall performance of the dessert cultivars was rated between fair and very good (Table 6). 'Laï', 'Kamaramasenge' and 'Kitika Sukari' were rated as acceptable (good or very good) by $>80 \%$ of the participants (Figure 2). 'To'o' was also acceptable to $>50 \%$ of respondents. 'Laii', 'Kamaramasenge' and 'Kitika Sukari' received the highest scores for pulp appearance, texture in hand and texture in mouth (Table 6). 'Kamaramasenge' and 'Kitika Sukari' scored highest for peel appearance, ease of peeling and overall acceptability. Taste scored highest for 'Kamaramasenge'. Only 'To'o' showed a significant difference between the mean scores given by the male and female panellists with males having significantly higher scores for pulp appearance. All dessert cultivars showed a significant positive correlation between their scores for texture in mouth and taste, and scores for overall acceptability. All but 'Laï' also showed a significant positive correlation between their scores for peel appearance and texture in hand, and scores for overall acceptability. 


\section{South Kivu}

\section{Boiled without peel}

The mean overall performance of the cultivars boiled without peel was rated good (Table 8). 'Musheba' and 'Barhebesha' were rated as acceptable (good or very good) by $>80 \%$ of the participants (Figure 3). 'Pelipita', 'Bira' and 'Lahi' were also acceptable to $>50 \%$ of respondents. 'Barhebesha' had significantly higher mean scores for all sensory attributes and overall acceptability than all the other cultivars (Table 8). 'Lahi' also scored well for aroma. Only 'Bira' showed a significant difference between the mean scores given by the male and female panellists with females having significantly higher scores for texture in the hand and overall acceptability. There was a significant positive relationship between the scores for the different sensory attributes, and the scores for overall acceptability, except for pulp appearance for 'Bira' (Table 9).

\section{Roasted without peel}

The mean overall performance of the cultivars roasted without peel was rated good (Table 8). 'Apantu' and 'Musheba' were rated as acceptable (good or very good) by $>80 \%$ of the participants (Figure 3). 'Bira' was also acceptable to $>50 \%$ of respondents. 'Apantu' and 'Musheba' received the highest scores for pulp appearance, texture in mouth, taste and overall acceptability (Table 8). No significant differences were found between the cultivars for aroma and texture in hand. Only 'Bira' showed a significant difference between the mean scores given by the male and female panelists, with females having significantly higher scores for taste and overall acceptability. There was a significant positive relationship between the scores for the different sensory attributes, and the scores for overall acceptability for all cultivars (Table 9).

\section{Pan-fried}

The mean overall performance of the pan-fried cultivars was rated good (Table 8). 'Apantu' and 'Musheba' were rated as acceptable (good or very good) by $>80 \%$ of the participants (Figure 3). 'Bira' was also acceptable to $>50 \%$ of respondents. 'Apantu' and 'Musheba' received the highest scores for pulp appearance, texture in mouth, taste and overall acceptability (Table 8). No significant differences were found between the cultivars for aroma and texture in hand. For all cultivars, there was no significant difference between the mean scores of the male and female panellists. There was a significant positive relationship between the scores for the different sensory attributes, and the scores for overall acceptability for all cultivars (Table 9).

\section{Dessert}

The mean overall performance of the dessert cultivars was fair to very good (Table 8). 'Gros Michel' was rated as acceptable (good or very good) by $>80 \%$ of the participants (Figure 3). 'Laï' was also acceptable to $>50 \%$ of respondents. 'Gros Michel' had significantly higher mean scores for all sensory attributes and overall acceptability than 'Laï' and 'To'o' (Table 8). Only 'Laï' showed a significant difference between the mean scores given by the male and female panelists, with males having significantly higher scores for overall acceptability. There was a significant positive relationship between the scores for the different sensory attributes, and the scores for overall acceptability for all cultivars (Table 9).

\section{General discussion}

Following evaluation of the peel appearance, ease of peeling, pulp appearance, aroma, texture in hand, texture in mouth, taste, and overall acceptability, the attributes that

TABLE 9. Correlation coefficients between sensory attribute scores and the overall acceptability scores of local (L) and introduced (I) banana cultivars in South Kivu, Democratic Republic of Congo.

\begin{tabular}{|c|c|c|c|c|c|c|c|c|c|}
\hline $\begin{array}{l}\text { Postharvest } \\
\text { treatments }\end{array}$ & Cultivars & $N$ & $\begin{array}{c}\text { Peel } \\
\text { appearance }\end{array}$ & $\begin{array}{l}\text { Ease of } \\
\text { peeling }\end{array}$ & $\begin{array}{c}\text { Pulp } \\
\text { appearance }\end{array}$ & Aroma & $\begin{array}{l}\text { Texture } \\
\text { in hand }\end{array}$ & $\begin{array}{c}\text { Texture } \\
\text { in mouth }\end{array}$ & Taste \\
\hline \multirow{6}{*}{$\begin{array}{l}\text { Boiled } \\
\text { without peel }\end{array}$} & 'Apantu' (I) & 150 & & & $0.48^{*}$ & $0.46^{*}$ & $0.44^{*}$ & $0.63^{*}$ & $0.78^{*}$ \\
\hline & 'Bira' (I) & 90 & & & 0.05 & $0.24^{*}$ & $0.38^{*}$ & $0.63^{*}$ & $0.63^{*}$ \\
\hline & 'Lahi' (I) & 150 & & & $0.31^{*}$ & $0.28^{*}$ & $0.27^{*}$ & $0.58^{*}$ & $0.80^{*}$ \\
\hline & 'Pelipita' (I) & 150 & & & $0.40^{*}$ & $0.47^{*}$ & $0.51^{*}$ & $0.75^{*}$ & $0.86^{*}$ \\
\hline & 'Musheba' (L) & 150 & & & $0.34^{*}$ & $0.30^{*}$ & $0.29^{*}$ & $0.65^{*}$ & $0.67^{*}$ \\
\hline & 'Barhebesha' (L) & 150 & & & $0.27^{*}$ & $0.47^{*}$ & $0.43^{*}$ & $0.56^{*}$ & $0.72^{*}$ \\
\hline \multirow{3}{*}{$\begin{array}{l}\text { Roasted } \\
\text { without peel }\end{array}$} & 'Apantu' (I) & 150 & & & $0.57^{*}$ & $0.59^{\star}$ & $0.44^{*}$ & $0.79^{*}$ & $0.90^{*}$ \\
\hline & 'Bira' (I) & 90 & & & $0.33^{*}$ & $0.54^{*}$ & $0.54^{*}$ & $0.69^{*}$ & $0.76^{*}$ \\
\hline & 'Musheba' (L) & 150 & & & $0.46^{*}$ & $0.55^{\star}$ & $0.27^{*}$ & $0.69^{*}$ & $0.83^{*}$ \\
\hline \multirow{3}{*}{ Pan-fried } & 'Apantu' (I) & 150 & & & $0.62^{*}$ & $0.70^{*}$ & $0.49^{*}$ & $0.81^{*}$ & $0.86^{*}$ \\
\hline & 'Bira' (I) & 90 & & & $0.36^{*}$ & $0.47^{\star}$ & $0.45^{\star}$ & $0.77^{*}$ & $0.81^{*}$ \\
\hline & 'Musheba' (L) & 150 & & & $0.44^{*}$ & $0.46^{*}$ & $0.51^{*}$ & $0.65^{*}$ & $0.80^{*}$ \\
\hline \multirow{3}{*}{ Dessert } & 'Laï' (I) & 149 & $0.44^{*}$ & $0.31^{*}$ & $0.37^{*}$ & $0.41^{*}$ & $0.36^{*}$ & $0.59^{*}$ & $0.56^{*}$ \\
\hline & 'To'o' (I) & 60 & $0.38^{*}$ & $0.45^{*}$ & $0.54^{*}$ & $0.31^{*}$ & $0.50^{*}$ & $0.69^{*}$ & $0.81^{*}$ \\
\hline & 'Gros Michel' (L) & 150 & $0.34^{*}$ & $0.35^{*}$ & $0.42^{*}$ & $0.47^{*}$ & $0.46^{*}$ & $0.55^{*}$ & $0.66^{*}$ \\
\hline
\end{tabular}

* Correlation coefficients between the different sensory attributes and the overall acceptability per postharvest treatment per banana cultivar (across rows) are statistically significant $(P<0.05)$.

$N=$ number of banana samples. 
showed the most significant correlation coefficients with the overall acceptability attribute were texture in mouth and taste. This can be explained by the fact that food is not solely regarded as a source of nourishment but is often consumed for the pleasure value it imparts, thus making it easier for people to give preference to food items that feel good in the mouth, i.e., have good/preferred texture in mouth. In addition, the great correlation coefficient between taste and overall evaluation can be explained by the fact that 'taste' is the sum of all sensory stimulation that is produced by the ingestion of a food: it brings together the smell, appearance and texture of food, thus contributing largely to whether an individual likes a particular food or not (Clark, 1998). With regard to appearance, consumers have been found to have a preference for large-sized bananas (Ahmed et al., 2007). This may explain the high scores for appearance of the local 'Musilongo' and the introduced 'Apantu' as these two Plantains have large finger sizes.

The characteristics of the individual consumer such as gender, education and age also have an impact on how food choices are made (Akankwasa et al., 2013). The attitudes, beliefs and expectations of an individual and their surroundings are able to mould the perception or acceptance of particular tastes and flavours (Clark, 1998). For this reason, sensory evaluation was carried out in more than one site, and by male and female panellists. There was no single cultivar for which differences in scores by male and female panellists were observed for each preparation method and/ or attribute assessed. South Kivu had the lowest number of cultivars with at least one attribute for which the male and female panellists had significantly different mean scores, with four attributes for 'Bira' (when boiled and roasted) for which females scored higher, and one attribute for 'Laï' for which males scored higher. Burundi and North Kivu on the other hand showed more variability in the scores by male and female panellists with eight and seven occurrences of significant differences respectively. In both these sites, males had significantly higher scores for each of the attributes in question, except for taste of boiled 'Gisahira' and texture in the hand of pan-fried 'Pelipita' in Burundi, and for the taste of 'Lahi' (when roasted without peel) in North Kivu. These results have a bearing during promotion and utilisation of these cultivars, whereby a cultivar, when prepared in different forms, can appeal to both the male household head and the female household head.

It is not surprising that overall the locally known cultivars scored higher values than the introduced cultivars, as these are what people are accustomed to. However, in each site and for each preparation method there was at least one test cultivar that received similar scores or had scores that came very close to the local cultivars, except for the dessert cultivars in all three sites. This supports our initial hypothesis. Similarly, when evaluating the acceptability of exotic and hybrid dessert bananas in Uganda, results indicated that, although the locally well-known dessert banana 'Gros Michel' was preferred to introduced dessert banana cultivars, the introduced cultivars were acceptable to the consumers with scores above 3 on a 5-point hedonic scale (Mugisha et al., 2008). It is also known that continued availability and consumption can also modify food preferences, such that over time, an acquired taste or preference is obtained (Clark, 1998).

\section{Conclusion}

Although local cultivars were generally preferred in all three sites, several tested cultivars were rated as acceptable by more than three quarters of the panellist, depending on the preparation:

- In Burundi, 'Apantu' showed to be a good alternative for the cooking types, especially when prepared boiled or roasted without peel and pan-fried; 'Bira' is another option for pan-fried cooking; 'Pelipita' and 'Lahi' are alternative cooking types for roasting with peel; and 'To'o' can be acceptable as a dessert type.

- In North Kivu, 'Apantu' again showed to be a good alternative for the cooking types, especially when prepared boiled or roasted without peel and pan-fried; 'Lahi' could be an alternative cooking type for roasting with or without peel or pan-frying; 'Laï' and 'To'o' are acceptable dessert types.

- In South Kivu, 'Apantu' once again showed to be a good alternative for the cooking types, especially when prepared boiled or roasted without peel and pan-fried.

The tested cultivars in general were acceptable to both men and women. The decision to adopt or consume a crop cultivar is influenced by production and consumption characteristics of the cultivars (Akankwasa et al., 2013). Based on the results of this study, the already observed and acceptable agronomic performance, bunch weight and growth cycles (Ekesa, 2016), coupled with capacity building and awareness creation, there is a high likelihood of inclusion and adoption of the introduced cultivars within existing farming systems and diets. As such these cultivars could contribute to increased access to dietary vitamin A among vulnerable population groups within banana-dependent populations, especially children and women.

\section{Acknowledgments}

The authors would like to thank HarvestPlus Challenge program through Bioversity International for funding this study. They are also grateful to the Consultative Group on International Agricultural Research (CGIAR) programs on Roots, Tubers and Banana (RTB) and Agriculture for Nutrition and Health (A4NH) for additional funding. Ms. Alice Simbare, Mr. Muller Kamira and Mr. Charles Sivirihauma, field scientists in Burundi, South Kivu-DRC and North Kivu-DRC are acknowledged for their support during the sensory evaluation exercise. Mr. Vincent Johnson and Ms. Anne Vézina, Bioversity International, Montpellier, France, are acknowledged for their support in editing this paper and translation of the abstract to French.

\section{References}

AATF-Africa (African Agricultural Technology Foundation) (2012). Improvement of banana for resistance to banana bacterial wilt disease in Africa. Retrieved from http://banana.aatf-africa.org/ improvement-banana-resistance-banana-bacterial-wilt-diseaseafrica on $11^{\text {th }}$ April 2015.

Ahmad, S., Akram, M.N., Hussain, Z., Anwar, R., and Thompson, A.K. (2007). Effect of fruit size and temperature on the shelf life and quality of ripe banana fruit. Sarhad J. Agric. 23(1), 45-54.

Akankwasa, K., Ortmann, G.F., Wale, E., and Tushemereirwe, W.K. (2013). Determinants of consumers' willingness to purchase East African highland cooking banana hybrids in Uganda. AJAR 8(9), 780-791. 
Ambuko, J., Sekozawa, Y., Sugaya, S., and Gemma, H. (2013). A comparative evaluation of postharvest quality attributes of two banana (Musa spp.) varieties as affected by pre-harvest production conditions. JAS 5(1), 170-178.

Arnaud, E., and Horry, J.P. (1997). Musalogue: a catalogue of Musa germplasm. Papua New Guinea collecting missions, 1988-1989 (Montpellier, France: INIBAP).

Caiubi-Pereira, L. (2009). Provitamin-A carotenoids content in Musa fruit: Genetic and ecological distribution and rapid pre-screening. M.Sc. Thesis, Institut Supérieur d'Agriculture de Lille, France.

Clark, J.E. (1998). Taste and flavour: Their importance in food choice and acceptance. Proc. Nutr. Soc. 57, 639-643. https://doi. org/10.1079/PNS19980093.

Dadzie, B.K., and Orchard, J.E. (1997). Routine post-harvest screening of banana/plantain hybrids: Criteria and methods. INIBAP Technical Guidelines, 2.

Davey, M.W., Van den Bergh, I., Markham, R., Swennen, R., and Keulemans, J. (2009). Genetic variability in Musa fruit provitamin A carotenoids, lutein and mineral micronutrient contents. Food Chem. 115, 806-813. http://dx.doi.org/10.1016/j.foodchem.2008.12.088.

Davey, M.W., Stals, E., Ngoh-Newilah, G., Tomekpe, K., Lusty, C., Markham, R., Swennen, R., and Keulemans, J. (2007). Sampling strategies and variability in fruit pulp micronutrient contents of West and Central African bananas and plantains (Musa species). J. Agric. Food Chem. 55(7), 2633-2644. https://doi.org/10.1021/ jf063119l.

Dowiya, N.B., Rweyemamu, C.L., and Maerere, A.P. (2009). Banana (Musa spp. Colla) cropping systems, production constraints and cultivar preferences in Eastern Democratic Republic of Congo. JAP $4(2), 341-356$.

Ekesa, B. (2016). Vitamin A Banana/Plantain. The 2nd Global Conference on Biofortification: Getting Nutritious Foods to People. Conference Brief no. 5a.

Ekesa, B.N., Poulaert, M., Davey, M.W., Kimiywe, J., Van den Bergh, I., Blomme, G., and Dhuique-Mayer, C. (2012). Bioaccessibility of provitamin-A carotenoids in bananas (Musa spp.) and derived dishes in African countries. J. Food Chem. 133, 1471-1477. https://doi. org/10.1016/j.foodchem.2012.02.036.

Ekesa, B.N., Kimiywe, J., Van den Berg, I., Blomme, G., Dhuique-Mayer, C., and Davey, M. (2013). Content and retention of provitamin-A carotenoids following ripening and local processing of four popular Musa cultivars from Eastern Democratic Republic of Congo. SAR 2(2), 60-75. https://doi.org/10.5539/sar.v2n2p60.

Ekesa, B., Nabuuma, D., Blomme, G., and Van den Bergh, I. (2015). Provitamin A carotenoid content of unripe and ripe banana cultivars for potential adoption in eastern Africa. J. Food Comp. Anal. 43, 1-6. https://doi.org/10.1016/j.jfca.2015.04.003.

Englberger, L., Darnton-Hill, I., Coyne, T., Fitzgerald, M.H., and Marks, G.C. (2003). Carotenoid-rich bananas: A potential food source for alleviating vitamin A deficiency. Food Nut. Bull. 24(4), 303-318. https://doi.org/10.1177/156482650302400401.

Fungo, R., and Pillay, M. (2011). Carotene content of selected banana genotypes from Uganda. AJB 10(28), 5423-5430.

International Food Policy Research Institute (2016). Global Nutrition Report 2016: From Promise to Impact: Ending Malnutrition by 2030 (Washington, DC: IFPRI).

Mugisha, J., Akankwasa, K., Tushemereirwe, W., and Ragama, P. (2008). Urban consumer willingness to pay for introduced dessert bananas in Uganda. ACSS 16(4), 251-258.
Stover, R.H., and Simmonds, N.W. (1987). Bananas. 3rd ed. Tropical Agricultural Series. (Essex, UK: Longman).

Uganda National Council for Science and Technology (2007). The biology of bananas and plantains. (Kampala: UNCST).

WHO (2009). Global prevalence of vitamin A deficiency in populations at risk 1995-2005. WHO database on Vitamin A deficiency. (Geneva: World Health Organization).

Received: Jul. 14, 2017

Accepted: Jul. 27, 2017 